\title{
TINGKAT KESUKAAN PADA STEAK IKAN CAKALANG (Katsuwonus pelamis L.) YANG DIRENDAM DALAM ASAP CAIR
}

\author{
Hasniar Hasan ${ }^{1}$, Bertie E. Kaseger ${ }^{2}$, Jenki Pongoh ${ }^{2}$ \\ 1) Mahasiswa pada Program Studi Teknologi Hasil Perikanan FPIK Unsrat Manado \\ ${ }^{2)}$ Staf pengajar pada Program Studi Teknologi Hasil Perikanan FPIK Unsrat Manado \\ Email: niarjiee86thp@yahoo.com
}

\begin{abstract}
Fogging is one way of preserving fish processing functions as well as providing odor as well as a simple way and has weaknesses. To over come these weaknesses, it can be attempted use of liquid smoke. The purpose of this study was to determine the level of preference of panelists and sticks $\mathrm{pH}$ value tuna mariheted in luquit smoke and followed by drying in an oven, the level of consumer preference were examined induced, appearance, odor, taste and consistency. The results were obtained of the average value $\mathrm{pH}$ sticks tuna were soaked in liquit smoke concentrations of $40 \%$ (A1), 5,52 and a concentrations of $50 \%$ (A2), 5,54 where as the concentrations of $60 \%$ (A3) is 5,31. Organoleptic appearance obtained average value is the concentration of $40 \%$ is 5,76 , whereas the concentration of $50 \%$ $6,39,60 \%, 6,7$. Organoleptic odor obtained an average value of $40 \%$, was 5,19 , the concentration of $50 \%, 5,93$, whereas the concentrations of $60 \%, 5,86$. Organoleptic taste obtained average concentrations value of $40 \%, 5,63$, concentration $50 \% 7,23$ and the concentrations of $60 \%$ is 7,10 . Concistency test gained an average of $40 \%, 5,76$ concentrations of $50 \%, 6,83$ whereas concentrations of $60 \%, 6,36$. Based on research results $\mathrm{pH}$ value test and organolptic test at level a tuna fish sticks, are soaked in liquit smoke has a low $\mathrm{pH}$ value, organoleptic, odor,appearance, consistencyhas an average value below 6 , while the value of the taste test average value above 7, found in concentrations of $50 \% 7,23$ and concentrations $60 \%$ values of 7,10 .
\end{abstract}

Keywords: $\quad$ Tuna (Katsuwonus pelamis L.). liquid smoke, pH and appearance quality.

Pengasapan merupakan salah satu cara pengolahan ikan yang berfungsi mengawetkan serta memberikan aroma dengan cita rasa yang khas. Produk olahan ini masih bersifat tradisional karena masih menggunakan cara sederhana dan memiliki kelemahan-kelemahan. Untuk mengatasi kelemahan tersebut, maka dapat di upayakan penggunaan Asap Cair. Tujuan dari penelitian ini adalah untuk mengetahui tingkat kesukaan panelis dan nilai $\mathrm{pH}$ steak cakalang yang direndam dalam asap cair dan dilanjutkan dengan pengeringan dalam oven, tingkat kesukaan konsumen yang diteliti meliputi : kenampakan, Bau, Rasa dan Konsistensi. Hasil penelitian diperoleh untuk nilai rata-rata $\mathrm{pH}$ steak Ikan Cakalang yang direndam Dalam Asap Cair konsentrasi 40\% (A1), 5,52 dan konsentrasi 50\% (A2), 5,54 sedangkan konsentrasi $60 \%$ (A3), adalah 5,31. Uji Organoleptik kenampakan diperoleh nilai rata-rata yaitu konsentrasi 40\%, adalah 5,76, konsentrasi 50\%, 6,39 sedangkan 60\%, 6,7. Uji Organoleptik Bau diperoleh nilai rata-rata konsentrasi $40 \%, 5,19$, konsentrasi 50\%, 5,93 sedangkan kosentrasi 60\%, 5,86. Uji Organoleptik Rasa diperoleh nilai rata-rata kosentrasi 40\%, 5,63 konsentrasi 50\%, 7,23 dan konsentrasi $60 \%, 7,10$. Uji Organoleptik Kosistensi diperoleh nilai rata-rata 40\%, 5,76, kosentrasi 50\%, 6,83 sedangkan kosentrasi $60 \%, 6,36$. Berdasarkan hasil penelitian Uji nilai $\mathrm{pH}$ dan Uji Organoleptik Tingkat Kesukaan pada Steak Cakalang yang direndam dalam Asap Cair memiliki nilai pH yang rendah, Uji Organoleptik Bau. Kenampakan, Kosnsistensi memiliki Nilai rata-rata di bawah 6, sedangkan untuk Nilai Uji Rasa Nilai rata-rata di atas 7, terdapat pada Konsentrasi 50\% dengan Nilai 7,23 dan Konsentrasi $60 \%$ Nilai 7,10.

Kata kunci: Ikan Cakalang (Katsuwonus pelamis L.), asap cair, uji mutu pH dan organoleptik.

\section{PENDAHULUAN}

Ikan merupakan salah satu sumber makanan yang sangat dibutuhkan oleh manusia karena mengandung protein. Dengan kandungan protein dan kandungan air yang cukup tinggi, ikan termasuk komoditi yang sangat mudah busuk (highly perishable). Oleh karena itu diperlukan upaya untuk menghambat proses pembusukan dengan cara pengawetan dan pengolahan. Salah satu pengolahan adalah dengan cara pengasapan (Afrianto dan Liviawati, 1989). 
Pengasapan merupakan salah satu cara pengolahan ikan yang berfungsi untuk mengawetkan serta memberi aroma dengan cita rasa yang khas, Di Sulawesi Utara ikan cakalang (Katsuwonus pelamis L.) merupakan sumber daya ikan yang potensial dikembangkan. Cakalang yang diasapi dikenal dengan sebutan Cakalang Fufu. Produk ini masih bersifat tradisional karena masih menggunakan cara sederhana yaitu dengan menggunakan bahan bakar kayu bakau bagi masyarakat didaerah pesisir pantai dan sebahagian menggunakan tempurung kelapa atau serabut kelapa didaerah pedalaman (Pongoh, 2001). Namun berbagai kemungkinan dapat terjadi pada sistem pengasapan tradisional seperti kualitas produk dihasilkan tidak konsisten, kandungan air tinggi, terakumulasinya senyawa yang berbahaya bagi kesehatan, pencemaran lingkungan dan kemungkinan terjadinya kebakaran (Darmadji, 1997). Disamping itu, efisiensi pengasapan sulit dikontrol serta waktu optimum dan suhu pengasapan tidak dapat dipertahankan (Maga, 1987).

Kelemahan tersebut kemungkinan dapat diatasi dengan penggunaan asap cair. Menurut Darmadji (1997) bahwa tempurung kelapa merupakan bahan baku pembuatan asap cair yang sangat baik karena mengandung senyawasenyawa anti oksidan dan anti bakteri yang tinggi. Selanjutnya menurut Gerasinov dan Antonova (1979) dalam Pongoh (2001) mutu ikan asap sangat tergantung pada kondisi permukaan ikan, suhu, kelembaban, konsentrasi asam dan komposisi kimia asap.

Berdasarkan penelitian ternyata untuk menghasilkan ikan asap bermutu tinggi sebaiknya digunakan jenis kayu yang mampu menghasilkan asap dengan kandungan unsur fenol dan asam organik cukup tinggi. Karena kedua unsur ini lebih banyak melekat pada tubuh ikan dan dapat menghasilkan rasa maupun warna daging ikan yang khas. Oleh karena itu pentingnya dilakukan penelitian untuk bisa melihat jumlah fenol yang berpenetrasi ke dalam daging ikan dengan perlakuan perendaman pada konsentrasi asap cair yang berbeda sehingga diharapkan dapat melekatkan partikel-partikel asap dan senyawa kimia yang terkandung didalamnya pada produk steak (potongan melintang) cakalang dan dilanjutkan dengan metode pengeringan agar bisa mempertahankan mutu dan daya simpan karena praktek pengeringan merupakan salah satu metode pengawetan ikan yang bertujuan mengurangi kadar air secepat mungkin agar bisa mencegah pembusukan.

Penelitian ini bertujuan untuk mengetahui tingkat kesukaan panelis terhadap Steak (potongan melintang) Ikan Cakalang dan nilai $\mathrm{pH}$ yang direndam dalam Asap Cair dan dilanjutkan dengan proses pengeringan dalam oven.

\section{METODOLOGI PENELITIAN}

Metode penelitian yang digunakan dalam penelitian ini adalah metode eksperimen eksporatif yaitu mengungkapkan fakta-fakta berdasarkan problema yang ada melalui hipotesa. Hadi (1970) menyatakan bahwa penelitian eksperimen eksploratif adalah penjelajah yang bermaksud mencari problemaproblema atau mengembangkan hipotesa tentang hubungan sebab akibat atau gejala.

\section{Tempat Dan Waktu Penelitian}

Pelaksanaan penelitian bertempat di Laboratorium Penanganan dan Pengolahan Hasil Perikanan dan Ilmu Kelautan. Universitas Sam Ratulangi Manado. Penelitian dilaksanakan selama 2 bulan (OktoberNovember 2014).

\section{Bahan Baku dan Alat}

Bahan baku yang digunakan adalah ikan cakalang yang sudah dipotong steak (melintang) dengan ukuran $3 \mathrm{~cm}, 1$ ekor ikan dipotong 3 bagian dan ketebalan $1 \mathrm{~cm}$ dengan berat ikan 150 gram. Jumlah ikan yang digunakan 6 ekor dengan berat $2 \mathrm{~kg}$. Bahan yang digunakan adalah asap cair.

Seperangkat alat pembuatan asap cair: tungku pembakaran, pipa besi dengan diameter $7,5 \mathrm{~cm}$ dan panjang pipa besi $110 \mathrm{~cm}$, pipa paralon dengan diameter $8 \mathrm{~cm}$ dan panjang pipa paralon $238 \mathrm{~cm}$, kotak pedingin dengan muatan sebanyak 10 Balok es, pipa pembuangan asap 6 $\mathrm{cm}$, tempat penampungan asap. mangkok kecil, kompor oven, sedangkan alat untuk pengujian nilai $\mathrm{pH}$ dan organoleptik antara lain : lembar penilaian, tissue, timbangan analitik, mortar, beker glass, $\mathrm{pH}$ meter.

\section{Perlakuan}

Perlakuan yang diterapkan dalam penelitian ini dirancang sebagai berikut: Perlakuan (A): konsentrasi asap cair 


$$
\begin{aligned}
& \text { A1 }=40 \% \\
& \text { A2 }=50 \% \\
& \text { A3 }=60 \%
\end{aligned}
$$

(B) $=30$ menit lama perendaman

Pengambilan Sampel data dalam penelitian ini dilakukan sebanyak dua kali.

\section{Tata laksana penelitian}

- Pembuatan Asap Cair dapat dilihat pada gambar 1.

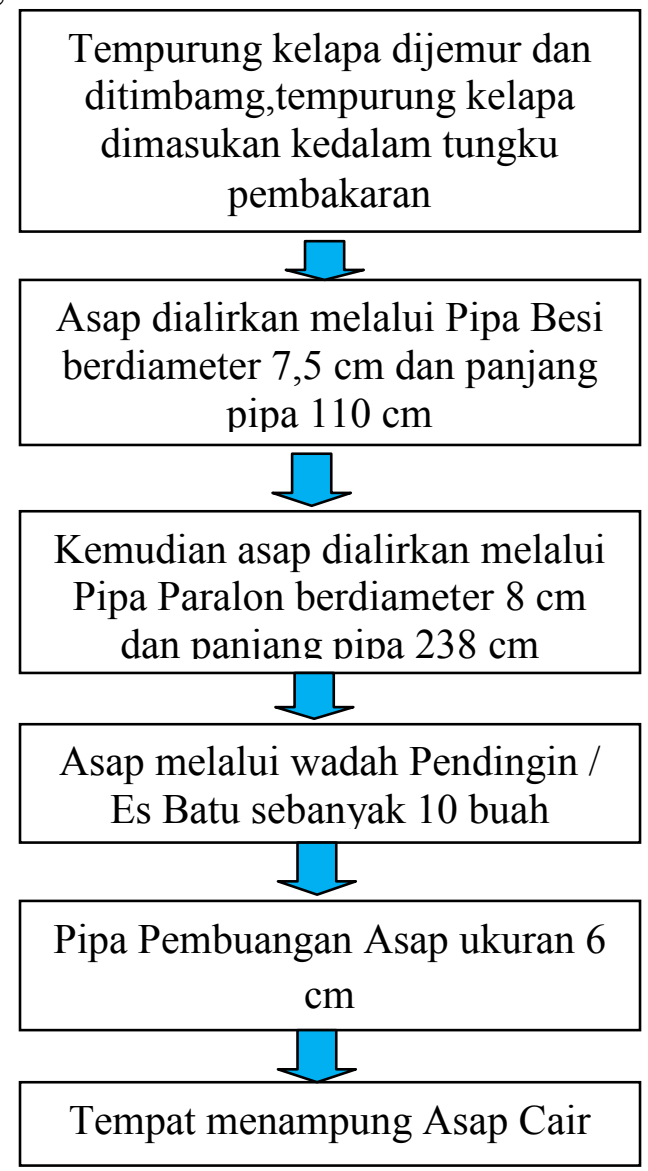

Gambar 1. Diagram alir pembuatan asap cair.

- Tempurung kelapa di jemur dan dipisahkan dari sabuk kelapa yang masih melekat, tempurung kelapa ditimbang dengan berat 48 $\mathrm{kg}$, hal ini dilakukan dengan tujuan untuk mengetahui efisiensi penggunaan bahan bakar.

- Setelah tempurung kelapa dibakar menjadi arang dimasukan kedalam tungku pembakaran dan dilakukan proses pembakaran yang menghasilkan asap.

- Asap hasil pembakaran dialirkan, melalui pipa-pipa paralon yang telah dihubungkan dengan tangki pembakaran, asap yang terdapat dalam pipa kemudian didinginkan dengan menggunakan es sebanyak 10 balok

\begin{tabular}{|c|}
\hline Ikan Cakalang (2 kg) \\
\hline 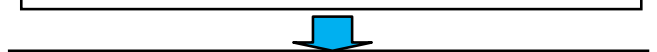 \\
\hline $\begin{array}{c}\text { Mengeluarkan Isi Perut, Insang, } \\
\text { Dan Sirip Ikan }\end{array}$ \\
\hline$L$ \\
\hline Dicuci Hingga Bersih \\
\hline 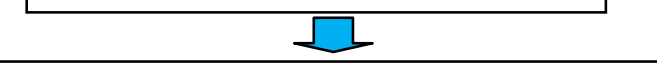 \\
\hline $\begin{array}{c}\text { Ikan dipotong steak, } 1 \text { ekor ikan } \\
\text { dipotong menjadi } 3 \text { bagian dengan } \\
\text { ukuran diameter } 3 \mathrm{~cm} \text { dan ketebalan } \\
1 \mathrm{~cm} \text { kemudian ikan dicuci kembali } \\
\text { untuk menghilang sisa darah. }\end{array}$ \\
\hline$\perp L$ \\
\hline $\begin{array}{c}\text { Steak ( potongan melintang ) } \\
\text { direndam dalam asap cair konsentrasi. } \\
\mathrm{A}_{1 .} .40 \% \\
\mathrm{~A}_{2 .} 50 \% \\
\mathrm{~A}_{3} .60 \% \\
\text { Selama } 30 \text { menit dengan } 2 \text { kali } \\
\text { ulangan }\end{array}$ \\
\hline
\end{tabular}

es sehingga terjadi proses kondensasi dimana asap akan berubah menjadi cairan.

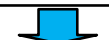

Steak ( potongan melintang ) cakalang dikeringkan dalam oven selama 2 jam dengan suhu $100^{\circ} \mathrm{C}$

Produk di analisa dilaboratorium (penentuan nilai $\mathrm{pH}$ dan Organoleptik)

Gambar 2. Diagram alir tatalaksana penelitian.

- Asap yang terbentuk lalu ditampung kedalam wadah yang telah dipasang pada ujung pipa dan jadilah Asap Cair.

- Tahapan selanjutnya untuk penelitian ini :

- Bahan Baku yang akan dilakukan untuk penelitian adalah ikan cakalang dengan berat $2 \mathrm{~kg}$ yang dibeli dari pasar bahu yang kemudian dibawa ke laboratorium.

- Setelah di laboratorium, ikan tersebut kemudian dicuci dan isi perut, ingsang, sirip ikan, dikeluarkan, dicuci bersih dipotongpotong melintang, setelah itu dicuci kembali agar menghilangkan sisa darah dari ikan 
tersebut, kemudian ditiriskan sampai sisa sisa air cucian ikan sudah tidak meleleh lagi.

- Setelah itu ikan direndam kedalam larutan asap cair dengan konsentrasi $40 \%$, konsentrasi $50 \%$ dan konsentrasi $60 \%$ selama 30 menit.

- Kemudian ikan dikeringkan dalam oven selama 2 jam.

- Setelah ikan tersebut kering, ikan lalu diangkat dan didinginkan untuk kemudian dilakukan pengujian Organoleptik dan di uji Nilai $\mathrm{pH}$.

- Untuk tahap selanjutnya dapat dilihat pada gambar 3 .

\section{Parameter Pengujian \\ Penentuan Nilai pH}

Menurut Suwetja, (2007), bahwa penentuan $\mathrm{pH}$ dapat dilakukan dengan menggunakan $\mathrm{pH}$ meter, dengan urutan kerja sebagai berikut:

- Timbang sampel yang telah dirajang kecilkecil sebanyak 20 gr di tambahkan $40 \mathrm{ml}$ aquades, dihomogenkan menggunakan mortar selama 1 menit.

- Tuangkan kedalam beker glass $40 \mathrm{ml}$, kemudian di ukur pH-nya dengan menggunakan $\mathrm{pH}$ meter.

- Sebelum pH meter digunakan, harus ditera kepekaan jarum petunjuk dengan larutan buffer $\mathrm{pH} 7$.

- Besarnya pH adalah pembacaan jarum petunjuk $\mathrm{pH}$ setelah jarum skala konstan kedudukannya.

\section{Uji Organoleptik}

Pengujian sensorial atau pengujian dengan indra atau dikenal juga dengan pengujian Organoleptik sudah ada sejak manusia mulai menggunakan indranya untuk menilai kualitas dan keamanan suatu makanan dan minuman (Setyaningsih, 2010).

Pengujian dilakukan para panelis yang semi terlatih yang berjumlah 15 orang dengan cara menyajikan sampel dan diberikan formulir untuk panelis pada setiap bahan uji. Pengujian Organoleptik dalam penelitian ini dilakukan uji kenampakan, bau, rasa, dan konsistensi. Sebelum panelis menilai atau mencontreng pada lembar score sheet, terlebih dahulu dijelaskan tentang cara-cara penilaian terhadap kenampakan, rasa, bau, dan konsistensi diberi nomor kode dan disajikan secara acak.

\section{HASIL DAN PEMBAHASAN}

\section{Nilai pH}

Data analisis nilai pH Cakalang Steak dapat dilihat pada tabel di bawah ini.

Tabel 1. Nilai pH steak ikan Cakalang (Katsuwonus pelamis L.).

\begin{tabular}{clr}
\hline Asap Cair & Ulangan & Nilai pH \\
\hline A1 ( Konsentrasi 40 \% ) & I & 5.53 \\
& II & 5.51 \\
& Jumlah & 11.04 \\
& Rata-rata & 5.52 \\
\hline A2 ( Konsentrasi $50 \%$ ) & I & 5.56 \\
& II & 5.52 \\
& Jumlah & 11.08 \\
& Rata-rata & 5.54 \\
\hline A3 ( Konsentrasi 60 \%) & I & 5.32 \\
& II & 5.30 \\
& Jumlah & 10.62 \\
& Rata-rata & 5.31 \\
\hline
\end{tabular}

Berdasarkan hasil penelitian diperoleh rata-rata nilai $\mathrm{pH}$ steak Ikan Cakalang dapat dilihat pada Gambar 3.

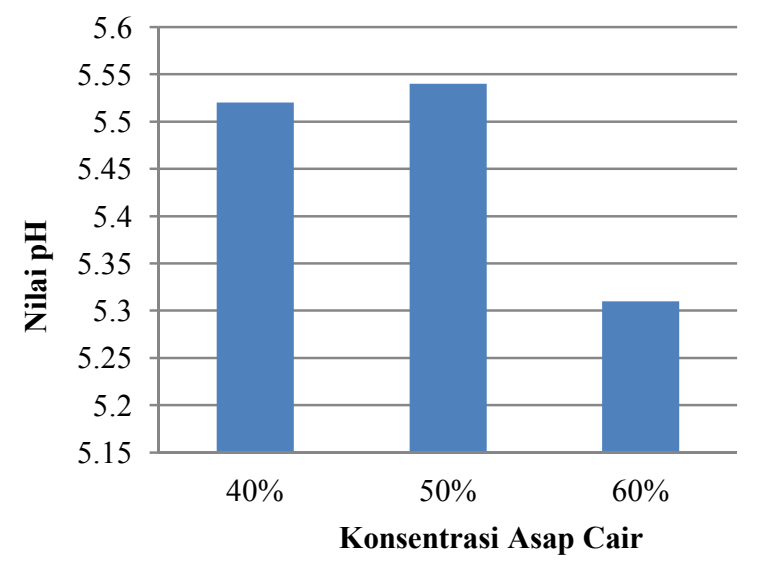

Gambar 3. Nilai pH steak Ikan Cakalang (Katsuwonus pelamis L.)

Nilai rata-rata $\mathrm{pH}$ steak ikan cakalang steak (potongan melintang). yang terendah adalah 5.31 pada konsentrasi asap cair $60 \%$ dan nilai $\mathrm{pH}$ tertinggi adalah 5,54, dengan konsentrasi asap cair 50\%. Juniarto (2003), menyatakan bahwa tinggi rendah $\mathrm{pH}$ ikan sangat tergantung pada jumlah glikogen yang ada.

\section{Uji Organoleptik \\ Kenampakan}

Hasil uji kenampakan tingkat kesukaan pada steak cakalang yang di rendam dalam asap cair dapat dilihat pada Tabel 2. 
Tabel 2. Data hasil pengamatan Nilai Uji Organoleptik kenampakan steak ikan Cakalang (Katsuwonus pelamis L.)

\begin{tabular}{ccccc}
\hline \multirow{2}{*}{ Asap Cair } & \multicolumn{2}{c}{$\begin{array}{c}\text { Nilai Organoleptik } \\
\text { kenampakan }\end{array}$} & Jumlah & $\begin{array}{c}\text { Rata- } \\
\text { rata }\end{array}$ \\
\cline { 2 - 3 } & Ulangan 1 & Ulangan 2 & & \\
\hline $40 \%$ & 5,4 & 6,13 & 11,53 & 5,76 \\
$50 \%$ & 6.73 & 6,06 & 12,79 & 6,39 \\
$60 \%$ & 7,4 & 6 & 13,4 & 6,7 \\
\hline
\end{tabular}

Berdasarkan data Tabel 4 tersebut dapat dilihat bahwa nilai rata - rata Kenampakan tertinggi adalah 6,7 yaitu pada perlakuan untuk konsentrasi $60 \%$ sedangkan nilai organoleptik kenampakan terendah adalah 5,67 pada perlakuan untuk konsentrasi $40 \%$.

\section{Bau}

Hasil uji Organoleptik Bau pada steak cakalang yang direndam dalam asap cair dapat dilihat pada Tabel 3 di bawah ini:

Tabel 3. Data hasil pengamatan nilai Uji Organoleptik Bau steak Ikan Cakalang (Katsuwonus pelamis L.).

\begin{tabular}{ccccc}
\hline \multicolumn{4}{c}{$\begin{array}{c}\text { Asap } \\
\text { Cair }\end{array}$} & \multicolumn{2}{c}{ Nilai Organoleptik Bau } & Jumlah & $\begin{array}{c}\text { Rata- } \\
\text { ratangan 1 }\end{array}$ & Ulangan 2 & & 5.19 \\
\hline $40 \%$ & 5.26 & 5.13 & 10.39 & 5.96 \\
$50 \%$ & 6.46 & 5.4 & 11.86 & 5.93 \\
$60 \%$ & 6.2 & 5.53 & 11.73 & 5.86 \\
\hline
\end{tabular}

Berdasarkan tabel data hasil pengamatan uji organoleptik Bau Steak cakalang yang direndam dalam asap cair tersebut dapat diketahui nilai rata-rata Organoleptik Bau yang tertinggi adalah 5.93 yaitu pada konsentrasi $50 \%$ sedangkan nilai rata-rata Organoleptik Bau yang terendah adalah 5.19 pada perlakuan $40 \%$.

\section{Rasa}

Hasil Uji Ortganoleptik Rasa pada steak ikan Cakalang (Katsuwonus pelamis L.) yang direndam dalam asap cair dapat dilihat pada Tabel 6 dibawah ini :

Tabel 4. Data hasil pengamatan nilai Uji Organoleptik Rasa Steak Ikan Cakalang (Katsuwonus pelamis L.).

\begin{tabular}{|c|c|c|c|c|}
\hline \multirow{2}{*}{$\begin{array}{l}\text { Asap } \\
\text { Cair }\end{array}$} & \multicolumn{2}{|c|}{ Nilai Organoleptik Rasa } & \multirow[b]{2}{*}{ Jumlah } & \multirow{2}{*}{$\begin{array}{c}\text { Rata- } \\
\text { rata }\end{array}$} \\
\hline & ulangan 1 & ulangan 2 & & \\
\hline $40 \%$ & 5,86 & 5,40 & 11,26 & 5,63 \\
\hline $50 \%$ & 7,66 & 6,80 & 14,46 & 7,23 \\
\hline $60 \%$ & 7,40 & 6,80 & 14,20 & 7,10 \\
\hline
\end{tabular}

Berdasarkan tabel tersebut dapat dilihat bahwa nilai rata-rata Organoleptik Rasa yang tertinggi adalah 7,23 yaitu pada konsentrasi
$50 \%$, sedangkan nilai uji organoleptik terendah adalah 5,63 dengan konsentrasi 40\%.

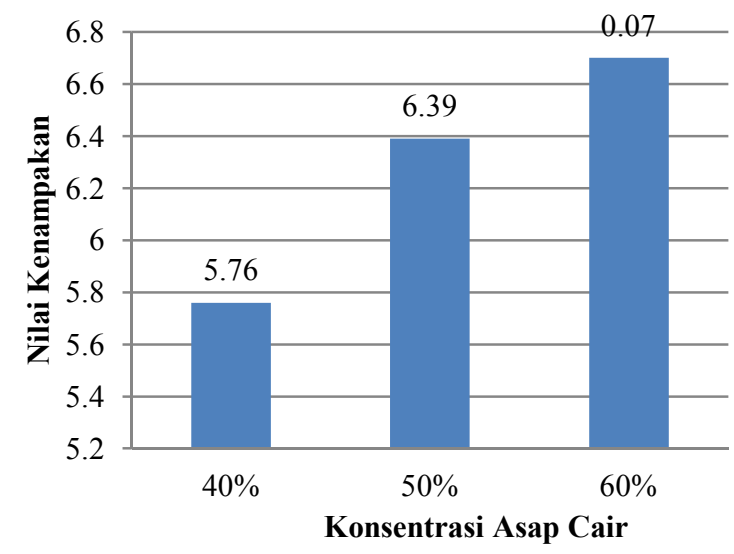

Gambar 4. Nilai Uji Organoleptik Kenampakan Steak Ikan Cakalang (Katsuwonus pelamis $\mathrm{L}$ ).

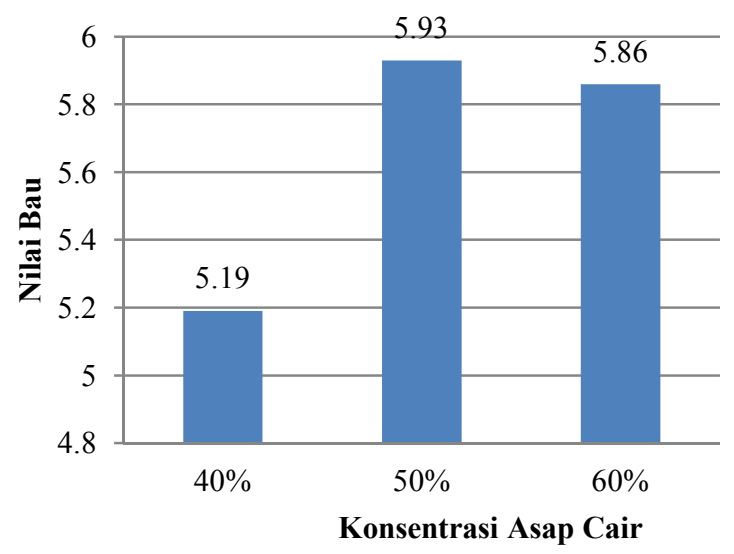

Gambar 5. Nilai Uji Organoleptik Bau steak Ikan Cakalang (Katsuwonus pelamis L.)

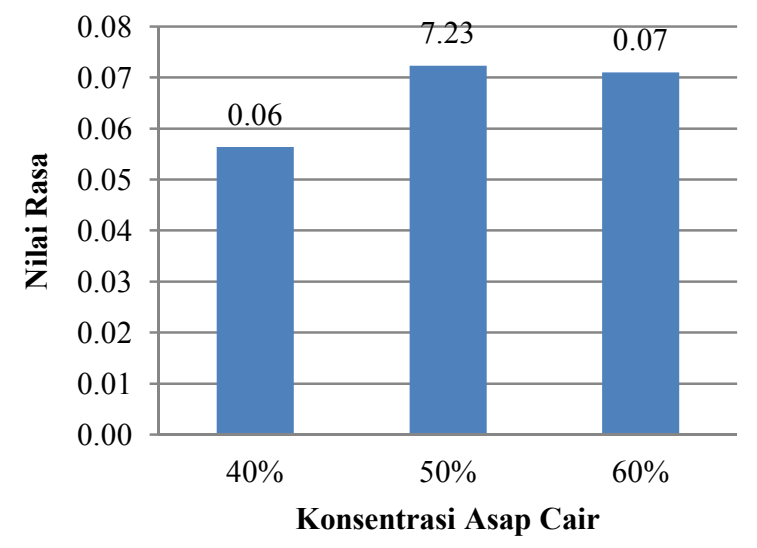

Gambar 6. Nilai Uji Organoleptik Rasa steak Ikan Cakalang (Katsuwonus pelamis L).

Berdasarkan gambar 6 dapat dilihat bahwa pada konsentrasi $40 \%$ memiliki nilai Organoleptik Rasa yang terendah, yaitu 5,63 
dan Konsentrasi 50\% memiliki nilai tertinggi yaitu 7,23 .

\section{Konsistensi}

Hasil Uji Organoleptik konsistensi Steak Ikan Cakalang yang direndam dalam asap cair dapat dilihat pada Tabel 7 berikut:

Tabel 5. Data hasil pengamatan nilai Uji Organoleptik Konsistensi steak ikan Cakalang (Katsuwonus pelamis L.)

\begin{tabular}{ccccc}
\hline \multirow{2}{*}{$\begin{array}{c}\text { Asap } \\
\text { Cair }\end{array}$} & \multicolumn{2}{c}{ Nilai Organoleptik Konsistensi } & Jumlah & $\begin{array}{c}\text { Rata- } \\
\text { rata }\end{array}$ \\
\hline $40 \%$ & Ulangan 1 & Ulangan 2 & & 11,52 \\
$50 \%$ & 5,66 & 5,86 & 5,76 \\
$60 \%$ & 7,20 & 6,46 & 13,66 & 6,83 \\
5,66 & 6,06 & 12,72 & 6,36 \\
\hline
\end{tabular}

Berdasarkan tabel tersebut dapat dilihat bahwa nilai rata-rata organoleptik Konsistensi yang tertinggi adalah 6,83 yaitu pada konsentrasi $50 \%$ sedangkan nilai rata-rata organoleptik yang terendah adalah 5,76 dengan konsentrasi $40 \%$.

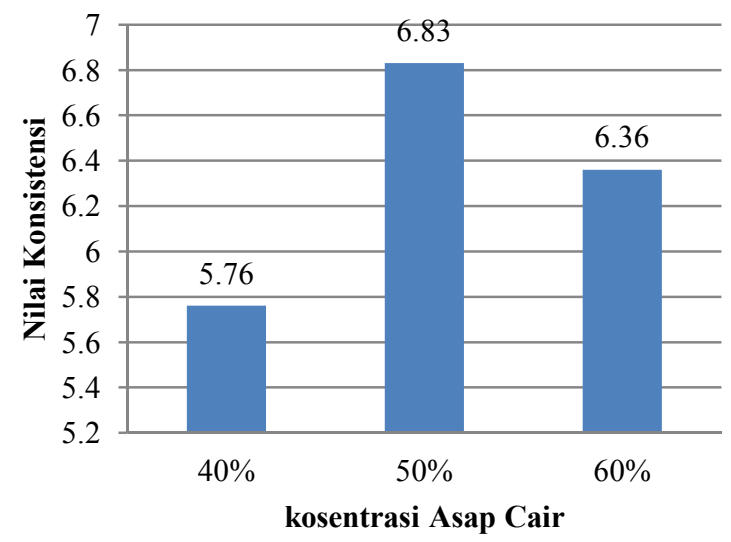

Gambar 8.Nilai Uji Organoleptik Konsistensi steak Ikan Cakalang (Katsuwonus pelamis L.).

Berdasarkan hasil penelitian Ruus (2009) dan Lukas (2011) menyatakan waktu pengeringan akan lebih besar menurunkan air dari dalam tubuh ikan. Hal ini disebabkan karena selama proses pengeringan, ikan menerima panas sehingga air dalam bahan menguap. Dengan berkurangnya jumlah air dalam produk ikan asap maka akan membuat Konsistensi darti produk ikan asap akan lebih baik.

\section{KESIMPULAN}

Berdasarkan hasil penelitian yang telah dilakukan maka dapat disimpulkan sebagai berikut:

1. Nilai pH, Steak Ikan Cakalang (Katsuwonus pelamis L.) yang direndam dalam asap cair dengan konsentrasi berbeda memiliki nilai rata-rata $\mathrm{pH}$ yang di dapatkan yaitu dengan konsentrasi 40\%, 5,52, konsentrasi $50 \%$, 5,54 dan konsentrasi $60 \% 5,31$.

2. Berdasarkan Uji Organoleptik.

- Tingkat kesukaan uji kenampakan didapatkan nilai rata-rata $40 \%$ adalah $5,76,50 \%$ adalah 6,39 dan $60 \%$ adalah 6,7 .

- Tingkat kesukaan uji Bau didapatkan nilai rata-rata $40 \%$ adalah $5,19,50 \%$ adalah 5,93 dan $60 \%$ adalah 5,86 .

- Tingkat kesukaan uji Rasa didapatkan nilai rata-rata $40 \%$ adalah $5,63,50 \%$ adalah 7,23 dan $60 \%$ adalah 7,10 .

- Tingkat kesukaan uji Konsistensi didapatkan nilai rata-rata $40 \%$ adalah $5,76,50 \%$ adalah 6,83 dan $60 \%$ adalah 6,36 .

\section{DAFTAR PUSTAKA}

Afrianto E,dan Liviawaty,1989. Pengawetan dan pengolahan ikan, penerbit Kanisius jogyakarta.

Darmadji, 1997. Aktifitas Anti Bakteri Asap Cair yang diproduksi dari bermacam-macam limbah pertanian. Agritech.

Hadi, S, 1970. Metodologi Research, Jilid 4. Andy, Yogyakarta.

Lukas, 2011. Kajian Mutu Ikan Kakap Merah (Lutjanus sp) yang diolah dengan pemberian kosentrasilarutan garamdan lama pengeringan yang berbeda. Skipsi. Fakultas Perikanan dan Ilmu Kelautan Universitas Sam Ratulangi. Manado.

Maga, 1987. Smoke iIn FoodProcessing Baracton, CRS, Florida : 1-9.

Pongoh, 2001. Penggunaan campuran asap cair kalium sorbet secara infiltrasi dantekanan saat pengemasan terhadap kestabilan mutu filettongkol (Euthynnus Spp) asap. Tesis. Universitas Brawijaya. Malang.

Ruus, 2009 Pengaruh kosentrasi Larutan Garam dan lama pengeringan terhadap mutu ikan dengan kadar garam rendah, Skripsi. Fakultas Perikanan dan Ilmu Kelautan Sam Ratulangi. Manado.

Setyaningsi, 2010. Analisis sensori untuk industry pangan. IPB Press. Bogor. 